\section{Justice is not egalitarian}

SIR - I disagree with the egalitarian concept of justice presented by Benno Müller-Hill in his Commentary "The shadow of genetic injustice" (Nature 362, $491-492 ; 1993$ ). We do not need "laws to protect the genetically disadvantaged". The purpose of laws is to establish a framework in which the force of the state may be used to protect the rights of individuals to life, liberty and property.

Individual rights can be violated only through the initiation of force or fraud by other individuals. This is not the case in Müller-Hill's third and fourth examples, which involve a prospective employee being refused employment on the basis of results of screening for a genetic disease.

The only basis for cooperation between free individuals is voluntary consent. There is no "right to a job" if nobody chooses to hire you. There is only the right to free trade - to take a job if offered one.

Laws that require businesses to employ people whom they would rather not are no better than laws in racist societies that forbid employers from hiring people of certain races who would otherwise be hired. They both violate the right of freedom of association.

Genetic screening is but one criterion in determining the market value of one's labour. Job seekers with genetic disease markers may enhance the value of their services by learning special skills in high demand or by lowering the price they ask for their services to give them an advantage. The biggest barrier to job-seekers with disabilities is coercive legislation that obliges employers to pay the medical insurance of their employees and laws that forbid disabled employees to work at a lower wage.

Müller-Hill offers us a choice between "the values of the Nazis and those of Moses". This is no choice at all. The alternative is not self-sacrifice to the nation or self-sacrifice to God. Man must learn to live for his own sake, neither sacrificing himself to others nor sacrificing others to himself.

Ron M. Kagan

12135 Mitchell Avenue, Apt 345,

Los Angeles, California 90066, USA

\section{NIH funding}

SIR - While we all would like to see more funding for the US National Insitutes of Health (NIH), significant increases are unlikely in the near future. However, the potential for significant changes exists within the current levels of funding. A disproportionate amount of funding goes to individuals with multiple grants at the expense of intellectual diversity. As the table illustrates, the average cost of a grant increases with the number of grants.

DISTRIBUTION OF NIH RESEARCH GRANT FUNDS, FISCAL 1991

\begin{tabular}{crrcc}
\hline $\begin{array}{c}\text { Grants } \\
\text { per } \\
\text { person }\end{array}$ & $\begin{array}{r}\text { No. of } \\
\text { people }\end{array}$ & $\begin{array}{c}\text { No. of } \\
\text { grants }\end{array}$ & $\begin{array}{c}\text { Annualamount } \\
\text { Average } \\
\text { amount per } \\
\text { grant }\end{array}$ \\
9 & 1 & 9 & $\$ 5,707,025$ & $\$ 634,114$ \\
7 & 4 & 28 & $\$ 13,579,534$ & $\$ 484,983$ \\
6 & 19 & 114 & $\$ 32,018,786$ & $\$ 280,867$ \\
5 & 31 & 155 & $\$ 50,957,134$ & $\$ 328,756$ \\
4 & 168 & 672 & $\$ 177,215,661$ & $\$ 263,714$ \\
3 & 729 & 2,187 & $\$ 565,995,895$ & $\$ 258,800$ \\
2 & 3,593 & 7,186 & $\$ 1,606,293,663$ & $\$ 223,531$ \\
1 & 15,263 & 15,263 & $\$ 2,940,907,779$ & $\$ 192,682$ \\
Totals & 19,808 & 25,614 & $\$ 5,392,675,477$ & \\
\hline
\end{tabular}

The data represent funding for all NIH research grants, excluding training grants and contracts. The amounts represent total costs including overhead. (Data courtesy Dr S. Joseloff, NIH Division of Research Grants.)

For every application funded, another must go unfunded. As one scientist collects his $n$-th grant, investigators only a few points lower in priority score are sent away with no funding. Because of the escalation of grant costs with number, if investigators were limited to a maximum of two grants (funded at the current average for two grants, about $\$ 400,000$ a year), 4,000 additional independent investigators could be funded each year. (The table underestimates the extent of funding inequity since it doesn't include NIH contracts, training grants, funding from other federal agencies, companies, endowment funds and so on.)

The academic research institutions in the United States value grants over results. Money brings power. By permitting grant hoarding, the NIH supports this executive reward system, with adverse consequences. Competent scientists are forced out of the system with zero funding. Junior faculty may not get tenure because they can't get (enough?) funding. Smart students, seeing the capriciousness of funding, leave science. Good scientists who become grant collectors are diverted to administration instead of science.

By limiting the maximum number of grants per principal investigator to two, the research establishment could be made healthier and more creative. As is recognized by a system of funding independent investigators, people do their best work when they are closely involved with the pursuit of their own ideas.

Frederick Sachs

Biophysical Sciences Channel Group, 120 Cary Hall,

State University at New York, Buffalo, New York 14214, USA

\section{Refused entry}

SIR - Political interference in the free exchange of ideas and scientists has often drawn criticism from the scientific community. For example, the inability of Israeli scientists to procure visas from the Soviet Union to attend the 14th International Genetics Congress led to a boycott of the congress and denunciations by many scientists (Nature 275, 577; 1978).

More recently, exclusion of South Africans by the United Kingdom (Nature 320, 3; 1986) and of HIV-positive individuals by the United States was greeted by protests. In both cases, the organizers saw fit to move the congresses as a result: the first from Southampton to Mainz, West Germany, and the second from Boston to Amsterdam.

Unfortunately, we must now report an additional case of political intrusion. A Cuban PhD student in our department, Gerardo Ferbeyre, was refused a visitor's visa by the United States. The refusal cites section 212(f) of the American Immigration and Nationality Act, "which prohibits the issuance of a visa to any person or class of persons whose entry into the United States is deemed by the president to be detrimental to the interests of the United States".

The visa was required by Ferbeyre to attend the conference "Catalytic RNAs (ribozymes) and gene therapy for the treatment of HIV infection" organized by the National Institute of Allergy and Infectious Diseases from 6 to 13 December 1992 .

Ferbeyre had been invited to attend the conference and to give an oral presentation of his work. Although we found it mildly amusing that the US government could feel so threatened by a single scientist, the fact remains that the accusations are specious and scandalous. Indeed, it could be ventured that the decision to refuse this visa would in itself be "detrimental to the interests of the United States" if one assumes that this interest includes either increased understanding of AIDS or the establishment of contacts with the Cuban intelligentsia.

An inquiry to the American Consulate in Montreal was bluntly rebuffed with a response to the effect that the American government does not welcome inquiries on the justification of visa decisions.

Apparently the convergence of political ideals that has taken place recently in the world is not to be interpreted to mean that scientists will be sheltered from arbitrary decisions in the future; however, by speaking out, the scientific community can defend the principle of the unimpeded access to scientific information which is so central to our common enterprise.

\section{John Bratty}

\section{Robert Cedergren}

Département de Biochimie,

Université de Montreál,

Montréal,

Québec H3C 3J7,

Canada

NATURE · VOL 363 - 17 JUNE 1993 